\title{
French AIDS campaign criticized as too soft by volunteer groups
}

Paris

THE French Ministry of Health launched the third part of its information campaign against AIDS (acquired immune deficiency syndrome) - a 20-second video clip - on all five channels of French television last week. The film, which is said to have cost the government FF7 million ( $\$ 1.13$ million), will be shown 90 times and shows a heterosexual couple intending to use a condom before having sex. The message of the film is "it won't pass on through us".

The film - and the government's AIDS UK barn owl decline cause for alarm

\section{London}

Changes IN weather patterns and farming methods have combined to cause an alarming decline in the population of the barn owl (Tyto alba) in Britain over the past 50 years. According to a census in 1932, there were then an estimated 12,000 pairs in

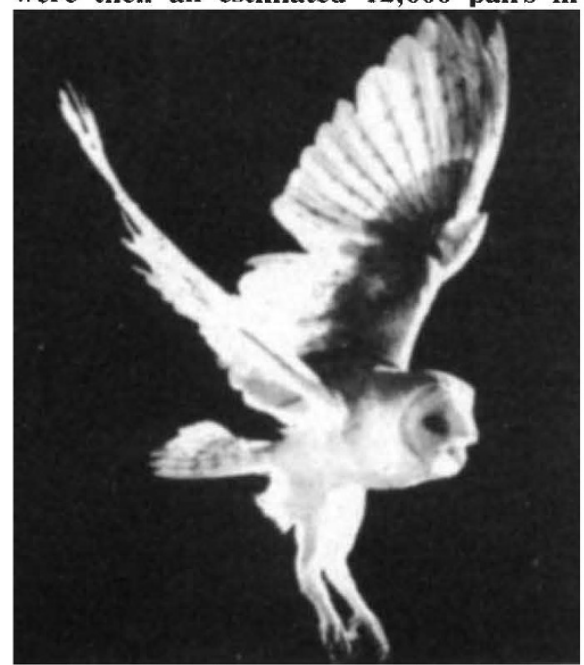

The barn owl - descending towards extinction? England and Wales. A study carried out between 1982 and 1985 by Dr Colin Shawyer, of the Hawk Trust, published this week*, shows that the 1932 figure has dwindled by nearly 70 per cent, to 3,750 .

The decline has been caused mostly by a reduction in the availability of food, impairing the birds' ability to breed successfully or to feed their young. Prolonged periods of snow, far more prevalent during recent years, have limited the owls' ability to find their staple diet of small rodents.

Modern farming methods have also made food harder to come by. The trend could be reversed by the immediate implementation of "effective conservation measures", including recreating grassland, says Shawyer. Simon Hadlington

* Shawyer, Colin. The Barn Owl in the British 1sles - its Past, Present and Future (The Hawk Trust, Freepost, Beckenham, Kent, f6.95.) prevention campaign in general - has already been criticized as being too soft and for missing high-risk populations altogether. So far this year, the government has printed 13 million leaflets on AIDS, 9 million of which have been delivered to telephone subscribers. The remaining 4 million are to be delivered to doctors' surgeries, the armed forces, universities and secondary schools. No special measures have been taken by the government to make sure that those most at risk - sexually active homosexuals, drug addicts and prostitutes - receive information on AIDS prevention.

The leitmotif of government advertising and politicians' speeches is that AIDS will be stopped only by giving money for medical research. The early success of the Pasteur Institute in isolating the virus causing AIDS made it possible for the search for an AIDS vaccine to become not only a "cause of national importance", but an occasion for national pride. This pride, according to critics, should not obscure the need for prevention. With 1,964 known cases of AIDS (the latest official figures) and over 150,000 carriers of HIV (human immunodeficiency virus) antibodies, France has the highest incidence of AIDS per head in Europe.

In response to the perceived weaknesses of the government information campaign, several voluntary AIDS information organizations have started in France. The Association pour la Prevention du SIDA has a 24-hour telephoneanswering service, although the recorded message only gives further numbers to ring. One of these numbers belongs to another group, called AIDS, which gives the times and numbers of telephone advice 'surgeries' throughout the country.

The most dynamic and perhaps effective organization is AJIS (Association de Jeunes pour l'Information sur le SIDA), a group of young people who have launched a 'no-holds barred' information campaign, using the FF500,000 $(\$ 81,000)$ donated by pop-singer Madonna after her Paris concert this year. This group has already made a film on safer sex and has distributed three different leaflets to secondary schools, in editions of 450,000 . The last edition contained a free condom, with clear instructions for its use.

This week, FF3.8 million $(\$ 613,000)$ was raised for the AIDS organization and for medical research by an auction of paintings. The French left-wing daily, Liberation, also carried a half-page open letter signed by 400 doctors belonging to SIDAventure, dedicated to "the development of a network of vigilance to ensure that medical opinion is not used for racist or segregationalist purposes". The letter was an open rejection of opinions expressed by Dr Bachelot, a member of the extreme right-wing National Front party, who had suggested imprisoning all AIDS patients in secluded "SIDAtoria".

- AN international ethics committee on AIDS is to be set up, following a suggestion mooted at the Venice summit in June. French President François Mitterrand has named France's representatives: Professor Jacques Ruffie, of the College de France; Alain Pompidou, technical adviser to the health ministry; and Dr Willy Rozenbaum, of the Claud Bernard hospital in Paris. President Reagan has selected as the US representatives Eugene Mayberry, of the Mayo Clinic at Rochester and president of the US AIDS commission; Charles McCarthy of the National Institutes of Health; and Leroy Walters of the Kennedy Institute at Georgetown University.

The French minister for research and higher education, Jacques Valade, has released funds set aside for AIDS research (see Nature 328, 191; 1987). FF20 million will go to industry as venture capital for the search for a vaccine. FF60 million will be divided between medical and science research institutes. Peter Coles

\section{Raman controversy puts award on ice}

\section{New Delhi}

The Indian National Science Academy (INSA) has ended an embarrassing twoyear controversy by deciding that offers of its coveted research awards will in future be withdrawn if those to whom they are made do not begin research within a year.

The decision arises from the award in January 1986 of the Sir C.V. Raman research professorship to Professor M.G.K. Menon, one of India's leading science administrators and a well-known cosmic-ray physicist who is now also the president of the International Council of Scientific Unions.

During 1985, Menon had apparently let it be known that he was thinking of quitting his job with the Planning Commission in favour of research, but, within a few days of the announcement of the award, he was named as the Prime Minister's science adviser and apparently decided to remain on the Commission as well.

According to an INSA spokesman, Menon's letter accepting the award, originally carrying a salary of 8,000 rupees a month, a contingency fund and the services of a research assistant, was received only in August this year, after reminders from academy officials, including Dr A.S. Paintal, the president since January 1987.

Menon will keep the Raman professorship until 1991, drawing a salary of one rupee a year.

K.S. Jayaraman 